\title{
Visceral Adhesions after Tension-Free Abdominal Wall Repair with Ultra-Lightweight Synthetic and Titanium-Containing Meshes
}

DOI: 10.17691/stm2017.9.3.06

Received July 24, 2016

V.V. Parshikov, MD, DSc, Professor, Department of Hospital Surgery named after B.A. Korolyov';

A.A. Mironov, PhD, Associate Professor, Department of Neurotechnologies, Institute of Biology and Biomedicine; Senior Researcher, Experimental Modeling Unit, Central Research Laboratory';

A.A. Kazantsev, Researcher, Scientific Methodological Department ${ }^{3}$;

A.I. Alyokhin, MD, DSc, Deputy Chief Physician for Scientific Work, Head of the Scientific and Educational Center ${ }^{3}$

1Nizhny Novgorod State Medical Academy, 10/1 Minin and Pozharsky Square, Nizhny Novgorod, 603005,

Russian Federation;

${ }^{2}$ Lobachevsky State University of Nizhni Novgorod, 23 Prospekt Gagarina, Nizhny Novgorod, 603950,

Russian Federation;

${ }^{3}$ Central Clinical Hospital of the Russian Academy of Sciences, 10 Fotiyeva St., Moscow, 119333, Russian Federation

Criteria of reliability and safety of abdominal wall prosthetic repair with the help of ultra-lightweight synthetic and titanium-containing materials are not clearly defined, and the results of their application are insufficiently studied.

The aim of the investigation was to study in the experiment the intensity of the abdominal adhesive process after tension-free repair with ultra-lightweight synthetic and titanium-containing meshes.

Materials and Methods. Ultra-lightweight synthetic and titanium-containing meshes were implanted to laboratory animals $(n=128)$. Synthetic meshes (PP Light) were used in group 1, in group 2 titanium-containing meshes (TiMesh) were employed, and in group 3 meshes were from titanium filaments (Titan, Titanium silk).

In the first series of the investigation, intraperitoneal onlay mesh (IPOM) technique was used, in the second series sublay retromuscular (SRM) repair was performed. 30 and 60 days later, the zone of implantation was examined with photofixation of the results, viscera-parietal adhesions were evaluated using a modified Vanderbilt assessment scale. Differences were considered statistically significant at $p<0.05$.

Results. The intensity of the adhesive process was significantly higher in the IPOM series (4.0 points) in comparison with the SRM series ( 0.44 points), $p=0.000$. The intensity of this phenomenon in the PP Light, TiMesh, and Titan groups amounted on average to 2.73 , 3.78 , and 5.33 points, respectively. Differences of the results in the TiMesh group from the PP Light group were not statistically significant, $p=0.07$, however, they were significant with the Titan group, $p=0.03$. The intensity depended also on the postoperative period duration. In the PP Light group its value on day 30 and 60 was 3.16 and 2.20 points, respectively, $p=0.22$; in the TiMesh group it was 3.64 and 4.0 points, respectively, $p=0.81$; in the Titan group it was 6.60 and $4.42, p=0.004$.

Minimal formation of viscera-parietal adhesions was noted in the SRM series: in the groups PP Light, TiMesh, and Titan it was equal to $0.36,0.44$, and 0.50 points, respectively. In some cases the zone of repair was completely free of adhesions. Adhesive process in the IPOM series should be considered unacceptably intensive in all periods for all tested meshes. In the SRM series, opposite (the best) results have been obtained, which were comparable for all types of meshes used in the work. Safety of retromuscular repair using ultra-lightweight synthetic and titanium-containing meshes has been convincingly proved by the data of the experiment.

Conclusion. Retromuscular repair with ultra-lightweight synthetic and titanium-containing meshes should be used for the reconstruction of the abdominal wall. But application of titanium-containing meshes seem to be more preferable, as it is associated with formation of significantly more strong connective tissue in the implantation zone, and an inflammatory reaction induced by such a mesh is substantially less than by a synthetic one.

Key words: prosthetic repair; synthetic meshes; titanium-containing meshes; mesh; hernia.

For contacts: Vladimir V. Parshikov, e-mail: pv1610@mail.ru 
Abdominal wall repair using meshes represents the main variant of surgical intervention in patients with incisional hernia [1-4]. Patients with hernia made a considerable part of sick people in general surgery units, and this fact determines an interest to the questions of their operative treatment [4-6].

The technique of surgical intervention is elaborated in detail and is being constantly improved [1-5]. Among numerous methods of operative aid, reconstruction (augmentation) and correction (bridging repair) are usually distinguished. Modern investigators pay increasing attention to the first method, the aim of which is not only to close the abdominal wall defect with a mesh, but to restore the latter as fully as possible in a way close to its initial (intact) structure [2, 3]. Not only prosthetic repair but also a reconstruction of the natural anatomy is supposed to be an indispensable condition of further functional activity of the abdominal wall as well as an adequate rehabilitation of a patient, his full physical activity, and ability to work.

Biomechanical concept of hernia pathogenesis envisages the necessity of restoring medial points of muscle attachment for the following proper functioning of the abdominal wall as a single muscular aponeurotic complex [7] and prevention of recurrence. In a number of cases, presence of the synthetic material results in excessive collagen synthesis, which is evident in formation of a large amount of unnecessary dense connective tissue, which lacks compliance and resilience. Formation of such scars is the basis for a stiff-man syndrome, making natural processes of contracting and stretching of the operated abdominal wall impossible.

The specified problem is being actively investigated by the leading specialists in the field of herniology. Experimental studies in this direction play a special role [8-10]. Of great importance in the assessment of the reparative process are the key aspects of interaction of the mesh material and structure with the components of the abdominal wall at the tissue level. Aseptic inflammation in the implantation zone is established to last in some cases for a long time and may become chronic. Prolonged local inflammatory reaction with the participation of the components of the cellular immunity link localized on the periphery of the implanted mesh is accompanied by the changes of the mesh elements themselves and the connective tissue formed around them. The indicated processes lead to the remodeling of the latter, alterations of its strength properties, compliance and extensibility. In clinical conditions it is a morphological basis of forming an operated abdominal wall as functionally inadequate, of stiff and rigid structure.

A combination of macrophage reaction, associated with chronic inflammation, and false-persisting mechanisms of biodegradation become the cause of diastases occurrence in the zone of "mesh fiberconnective tissue" contact typical for late recurrences after prosthetic repair [11]. The described above phenomena are pathogenically connected with a number of remote complications of the tension-free technique. And abdominal adhesive process is referred to them [12-15]. The pathogenesis of forming visceraparietal and viscera-visceral adhesions is described in detail in the literature [16]. Clinically important disorders of intestinal content passage may result in the development of acute intestinal obstruction. In some cases, migration of meshes to the abdominal cavity is observed [17], mesh forms pressure sores on the walls of the hollow organs and enterocolonic fistulas [18]. Chronic accumulations of fluid (seromas) and development of chronic pain syndrome are typical situations for the persisting paraprosthesis inflammation. In case of forming paraprosthesis granulomas and mesh fistulas, bacterial contamination and biofilm process may play a role [19]. Mechanisms of seroma formation are considered in detail in the literature [20, 21]. The work on the problem of forming a fully functional connective tissue in the implantation zone and achieving complete integration of the mesh in the tissues of the abdominal wall implies solving a complex of interconnected tasks concerning improvements of the surgical technique, development of new meshes, optimization of the reparative process course, and prevention of infections in the area of operative intervention.

The advent of a new group of ultra-lightweight meshes as a means of abdominal wall reconstruction is connected with definite hopes of investigators to avoid a number of complications typical for heavy and standard meshes. For some authors [22], application of these meshes is associated with favorable clinical results, in other works [8] similar materials are not recommended for routine usage.

Apart from the well-known synthetic materials, titanium-containing meshes are actively implemented into herniological practice in recent years. This is a new group of implants possessing some advantages, and their fabrication is based on principally different technological processes [23, 24]. In some publications their capabilities have been appreciated as rather high, the authors report good experimental and clinical results [23-29].

Criteria of reliability and safety of abdominal wall prosthetic repair with the help of ultra-lightweight synthetic and titanium-containing materials are not clearly defined, and the results of their application including development of complications, the adhesive process in particular, are insufficiently studied.

The aim of the investigation was to study in the experiment the intensity of the abdominal adhesive process after tension-free repair with ultra-lightweight synthetic and titanium-containing meshes.

Materials and Methods. Meshes were implanted to the laboratory animals. Interventions were done with the permission of the Ethic Committee of the Central Clinical Hospital of the Russian Academy of Sciences in compliance with the legislation of the Russian Federation (Rules of humane treatment of laboratory 
animals, Deontology of medico-biological experiment) and ethical principles established by European Convention for the Protection of Vertebrate Animals used for Experimental and other Scientific Purposes (the Convention was passed in Strasburg, March 18, 1986, adopted in Strasbourg, June 15, 2006). The experiment was carried out in the M.M. Shemyakin and Yu.A. Ovchinnikov Institute of Bioorganic Chemistry of the Russian Academy of Sciences (Moscow).

The study design, formation of groups, methodology of operations, anesthetic support, and management of the postoperative period fully corresponded to the postulates of the modern $3 \mathrm{R}$ concept (replacement, reduction, refinement) of Russell \& Burch commonly accepted in the world and obligatory for observance in biology and experimental surgery [30].

Meshes $(n=128)$ were implanted to rabbits under anesthesia using intramuscularly the following medications: Rometar (xylazine hydrochloride, $2 \mathrm{mg} / \mathrm{kg}$ ) and Zoletil (tiletamine hydrochloride/zolazepam hydrochloride, $8 \mathrm{mg} / \mathrm{kg}$ ). In group 1, synthetic meshes (PP Light, polypropylene fiber of $90 \mu \mathrm{m}$ in diameter, $36 \mathrm{~g} / \mathrm{m}^{2}$ surface density, $39.6 \mathrm{~cm}^{3} / \mathrm{m}^{2}$ index of the distributed volume) were used. According to Klinge and Klosterhalfen classification [31], this corresponds to the category of lightweight meshes [32] class 1a. In some papers $(2014,2015)$ the authors consider these meshes ultra-lightweight [8, 33]. Titanium-containing meshes were used in group 2 (TiMesh, polypropylene fiber of $65 \mu \mathrm{m}$ in diameter with a titanium coating, $16 \mathrm{~g} / \mathrm{m}^{2}$ surface density, $17.58 \mathrm{~cm}^{3} / \mathrm{m}^{2}$ index of the distributed volume). Such meshes are referred to 1c class [31] and ultra-lightweight meshes [8, 32, 33]. In group 3, meshes

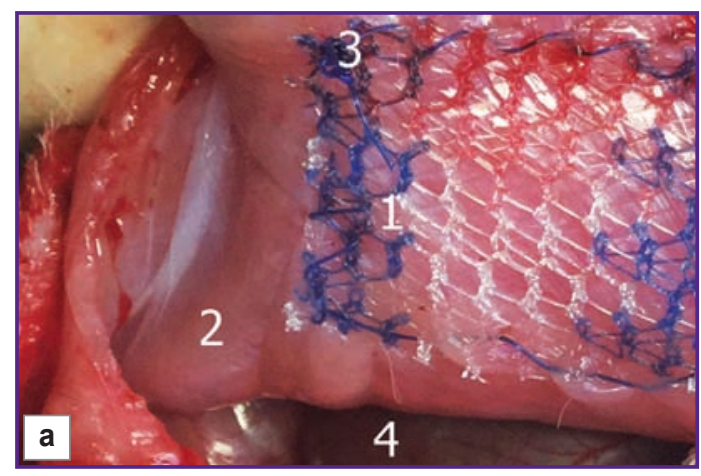

Figure 1. Intraperitoneal implantation (IPOM):

(a) PP Light meshes; (b) TiMesh meshes; (c) Titan meshes; (1) mesh; (2) peritoneum; (3) ligature; (4) intestine

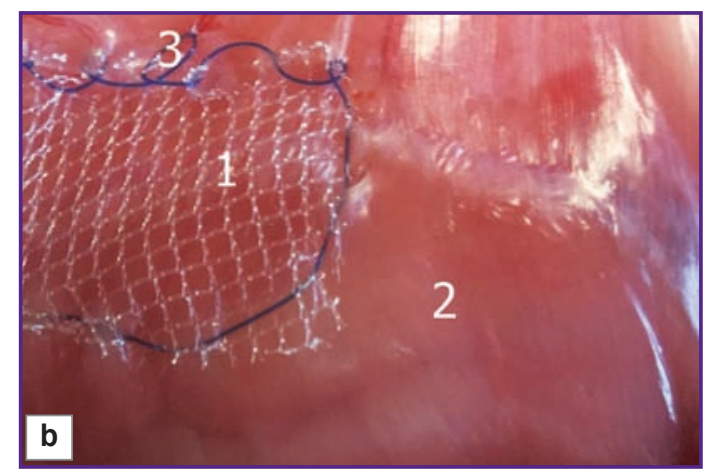

from titanium fibers were implanted (Titan, Titanium silk, $65 \mu \mathrm{m}$ filament, $45 \mathrm{~g} / \mathrm{m}^{2}, 10.41 \mathrm{~cm}^{3} / \mathrm{m}^{2}$ index of the distributed volume). These meshes are ultra-lightweight $[8,33]$. All described meshes pertained by their structure to the meshes woven from monofilament fibers.

The operative technique was standard for experimental works $[12,34]$, the implantation procedure in the clinical environment was also typical. For adequate comparison of the results, intraperitoneal onlay mesh (IPOM) [5, 14] and sublay retromuscular (SRM) methods of plastic repair $[1,35]$ actively used in current herniology were chosen. For correct collation of the research data, standard dimensions of meshes $(3 \times 3 \mathrm{~cm})$ were used, which were applied in our previous works and described by other authors [36-38]. The meshes were attached to the structures of the abdominal wall with an atraumatic synthetic thread 4/0 (polypropylene).

The distribution of operations by series and groups is presented in Table 1. By the time of intervention the rabbits weighed $3,495 \pm 345 \mathrm{~g}$.

In the first series of the investigation, IPOM method was used (Figure 1). Midline laparotomy was performed.

Table 1

Performance of implantations in the groups of animals (abs. number)

\begin{tabular}{lcccc}
\hline \multirow{2}{*}{ Series } & \multicolumn{3}{c}{ Groups } & Total \\
\cline { 2 - 4 } & PP Light & TiMesh & Titan & \\
\hline IPOM & 22 & 18 & 24 & 64 \\
\hline SRM & 22 & 18 & 24 & 64 \\
\hline Total & 44 & 36 & 48 & 128 \\
\hline
\end{tabular}

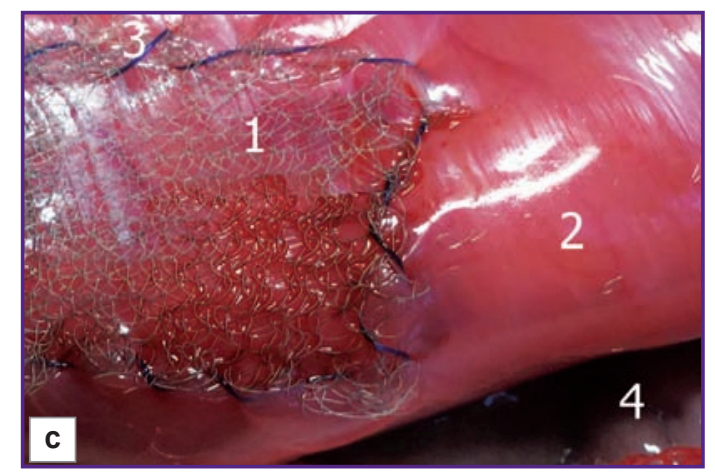



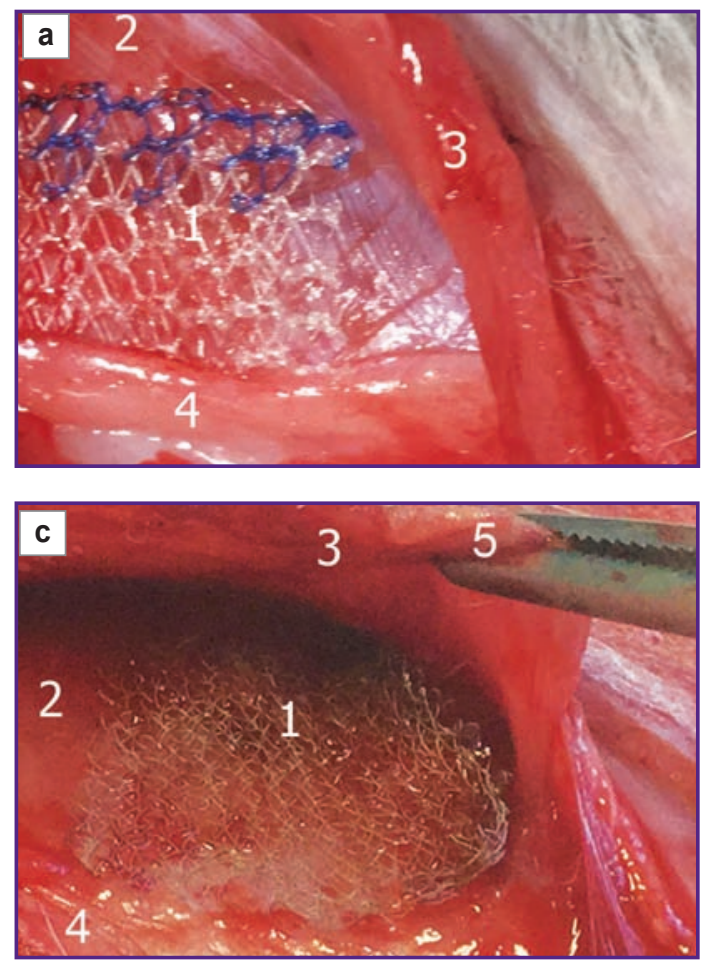

Table 2

The scale of adhesive process assessment in the zone of plastic repair (according to Yegiyev and Lyadov, 2010)

\begin{tabular}{|c|c|}
\hline $\begin{array}{l}\text { Adhesive process } \\
\text { area (0-4 points) }\end{array}$ & $\begin{array}{l}\text { No adhesions }-0 \\
\text { Up to } 25 \% \text { of the mesh area }-1 \text { point } \\
\text { From } 25 \text { to } 50 \% \text { of the mesh area }-2 \text { points } \\
\text { From } 50 \text { to } 75 \% \text { of the mesh area }-3 \text { points } \\
\text { More than } 75 \% \text { of the mesh area }-4 \text { points }\end{array}$ \\
\hline $\begin{array}{l}\text { Adhesion strength } \\
\text { (0-3 points) }\end{array}$ & $\begin{array}{l}\text { No adhesions }-0 \\
\text { Easily separated }-1 \text { points } \\
\text { Separated by the instrument }-2 \text { points } \\
\text { May be separated only by sharp dissection - } \\
3 \text { points }\end{array}$ \\
\hline
\end{tabular}

N o t e. Points are summed up amounting from 1 to 7 .

Mesh was fixed to the parietal peritoneum from the side of the abdominal cavity, then the abdominal cavity and the wound were closed with a continuous suture using an atraumatic synthetic thread.

In the second series of interventions, SRM method was employed (Figure 2). Midline laparotomy was performed. Anterior laminae of the rectus abdominis sheaths were medially dissected, retromuscular space was bilaterally prepared. The abdominal cavity was closed by a continuous suture using an atraumatic synthetic thread, posterior laminae of the rectus abdominis sheaths were joined. A mesh was placed in the retromuscular space, fixed to the posterior laminae of the sheath with an atraumatic synthetic thread $4 / 0$ without tension. Anterior laminae of the rectus abdominis sheaths were joined by

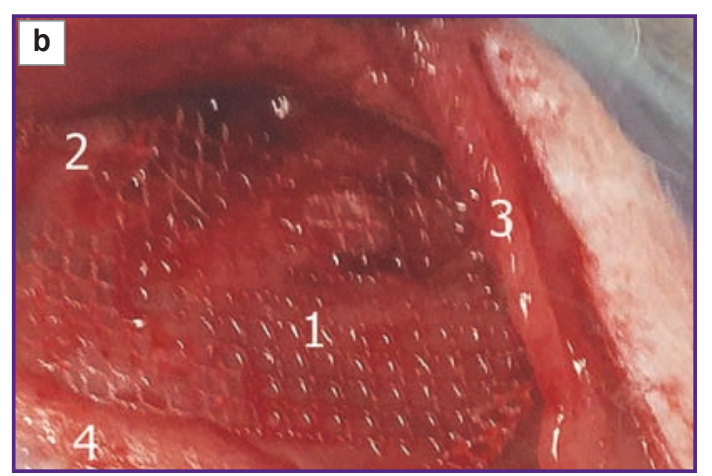

Figure 2. Retromuscular implantation (SRM):

(a) PP Light meshes; (b) TiMesh meshes; (c) Titan meshes; (1) mesh; (2) posterior lamina of the rectus abdominis sheath; (3) rectus muscle; (4) white line; (5) instrument

a continuous suture using an atraumatic synthetic thread, thereafter the wound was closed.

To prevent infections in the area of surgical intervention a single injection of beta-lactam antibiotic was made, the dosage was calculated depending on the animal body mass. Food, water, and movement regimens were not limited. Non-narcotic analgesics were routinely used. Animals were followed up for 2 months. They were withdrawn from the experiment under anesthesia using the above-mentioned drugs in the same dosage by means of air embolism $(7 \mathrm{ml} / \mathrm{kg})$. The implantation zone was inspected with photofixation of the results with special attention to the assessment of viscero-parietal adhesions.

The score (from 0 to 7 points, Table 2) was counted according to the modified scale of Vanderbilt University [34]. Distribution of the population data was evaluated by Shapiro-Wilk and Lilliefors (Origin Pro 8) tests. The analysis of nonparametric sequences was done using Mann-Whitney and Kolmogorov-Smirnov methods (Origin Pro 8). Data arrays with normal distribution were studied using Student's t-test (Excel 2016). Differences were considered significant at $p<0.05$.

Results. The postoperative period was uneventful in all animals, the wounds healed by primary intention. Animal body mass at the beginning of the experiment was $3,495 \pm 345 \mathrm{~g}, 30$ days later it became $3,420 \pm 477 \mathrm{~g}$ (i.e. less than the initial mass, $p=0.03$ ), 60 days later it reached $3,808 \pm 470 \mathrm{~g}$ (i.e. greater than the initial value, $\mathrm{p}=0.014$ ).

The intensity of the adhesive process was statistically higher in the IPOM series (4.0 points) compared to the SRM series ( 0.44 points), $p=0.000$ (Table 3 ). 
Table 3

Intensity of the adhesive process (points)

\begin{tabular}{lcccc}
\hline \multirow{2}{*}{ Series } & \multicolumn{4}{c}{ Group } \\
\cline { 2 - 5 } & PP Light & TiMesh & Titan & Mean* \\
\hline IPOM & 2.73 & 3.78 & 5.33 & 4.00 \\
\hline SRM & 0.36 & 0.44 & 0.50 & 0.44 \\
Mean & 1.55 & 2.11 & 2.92 & 2.22 \\
\hline
\end{tabular}

* Arithmetic mean.
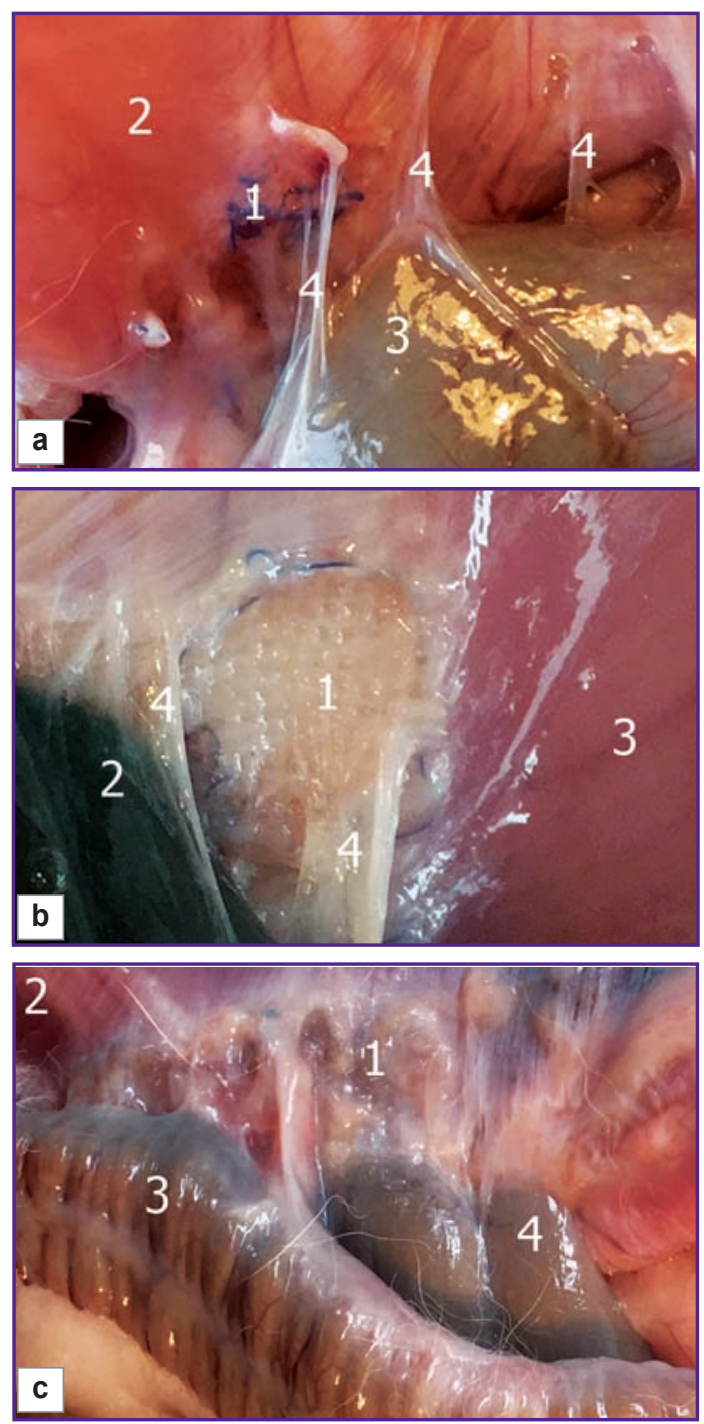

Figure 3. The result of intraperitoneal implantation (IPOM): (a) PP Light meshes; (b) TiMesh meshes; (c) Titan meshes; (1) mesh; (2) peritoneum; (3) intestine; (4) adhesions. Adhesive process

Formation of viscero-parietal adhesions is shown on Figure 3. The extent of this phenomenon in the PP Light, TiMesh, and Titan groups corresponded on average to $2.73,3.78$, and 5.33 points. A definite tendency was found when a more comprehensive comparison was performed within the IPOM series: the intensity of the adhesive process depended on the kind of a mesh in case of intraperitoneal repair. In particular, when the PP Light and TiMesh groups were compared, differences were not statistically significant, $p=0.07$. However, they were significant, $p=0.03$, when the TiMesh and Titan groups were collated.

The intensity of the adhesive process depended also on the postoperative terms. In the PP Light group it was 3.16 and 2.20 points on day 30 and 60 , respectively, $p=0.22$; in the TiMesh group it was 3.64 and 4.0 points on day 30 and 60 , respectively, $p=0.81$; and in the Titan group in later terms of the postoperative period the intensity of the adhesive process appeared to be statistically significantly less: 6.60 and 4.42 points, respectively, $p=0.004$.

Minimal formations of viscera-parietal adhesions were noted in the SRM series (Figure 4). The measured index
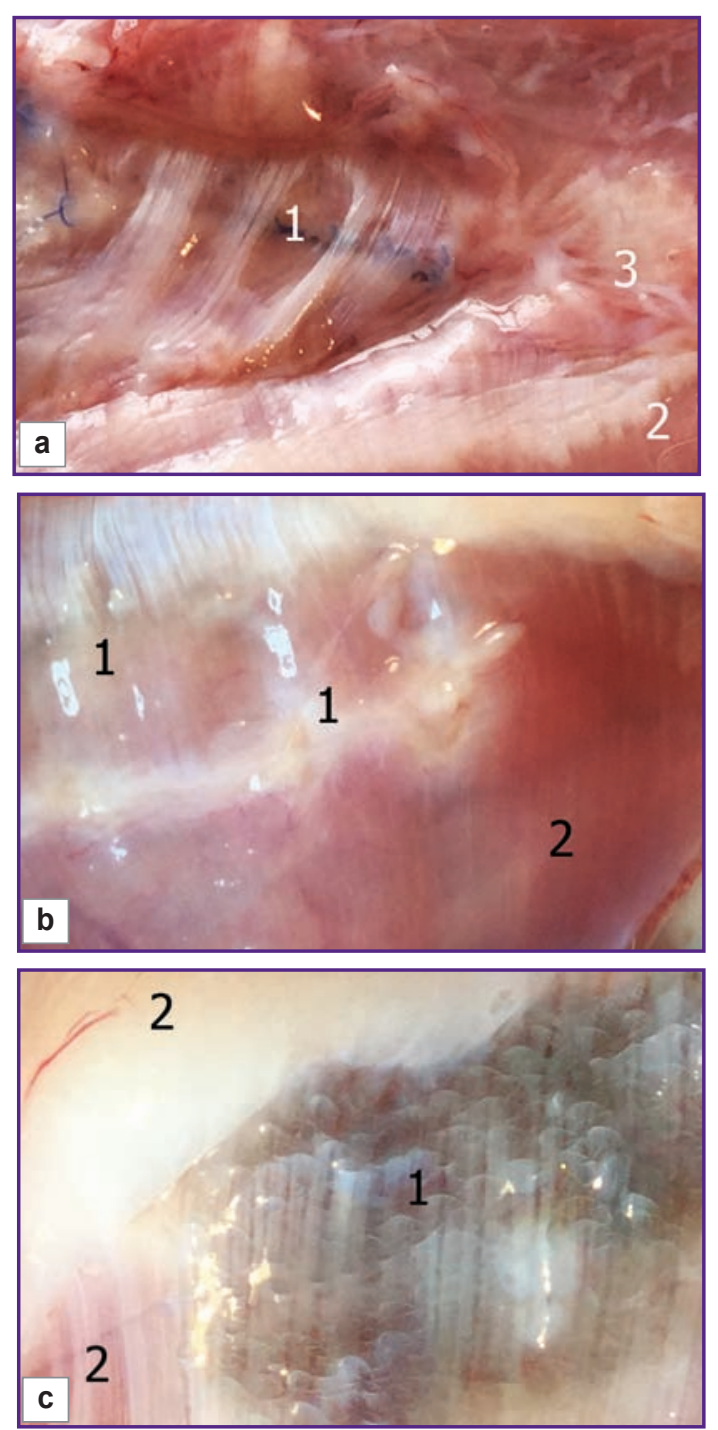

Figure 4. Results of retromuscular implantation:

(a) PP Light meshes; (b) TiMesh meshes; (c) Titan meshes; (1) mesh; (2) peritoneum; (3) zone of abdominal wall suture. Absence of the adhesive process 
in the PP Light, TiMesh, and Titan groups was 0.36, 0.44 and 0.50 points, respectively, $p=0.76$ (See Table 3). In some cases the zone of repair was completely free of adhesions. Application of the mesh from titanium filaments for the retromuscular repair, the usage of which in the IPOM series was associated with the highest value according to the scale of adhesion process, did not also show a marked formation of adhesions. On Figure 4 (c), it is well seen how the titanium mesh literally shines through very thin structures of the posterior layers of the rabbit abdominal wall. Nevertheless, the significant viscero-parietal adhesive process is not observed.

The result of the conducted study allows us to assert that formation of viscero-parietal adhesions associated with implantation of ultra-lightweight synthetic and titanium-containing meshes significantly depends on the chosen method of the abdominal wall endoprosthetic repair. It is true for all tested implants and periods of follow up. In the IPOM series, statistically significant reduction of the adhesive process intensity was found in the late terms of the postoperative period for Titan implants. In the same series, statistically significant differences of viscero-parietal adhesion formation between the examined groups were revealed. Nevertheless, the adhesive process in the IPOM series should be considered to be unacceptably intensive in all periods for all tested meshes. In the SRM series the opposite (the best) results were obtained, which were comparable for all types of meshes used in the work. Safety of retromuscular repair by the ultra-lightweight synthetic and titanium-containing meshes has been convincingly proved by the experimental data.

Discussion. The data given within the scope of the current investigation are subject to a detailed comparison with the findings of other studies and thorough critical analysis. Upon the whole, the obtained indices of the viscero-parietal adhesive process intensity agree in many ways with other similar measurements [12, 34, 36-38], though there are some differences. However, data about implantation of the titanium meshes are published for the first time in the present work.

In the series of intraperitonial repair with ultralightweight meshes, the intensity of the adhesive process was lower than the analogous indices for standard meshes presented previously by the Russian leading scientists [12, 34]. The same authors prefer using lightweight meshes in the clinical environment, placing them extraperitonially [22]. Other investigators use these meshes intraperitonially [5]. In the existing situation, one can only suppose that probably there are some advantages of using the light and ultra-lightweight implants, but not assert that they must be placed intraperitonially, as investigations on this topic have not been found.

The obtained indices of the adhesive process intensity for the PP Light implanted according to IPOM technique agree with the previous investigations [37], in which close values of 3.77 points ( $\mathrm{M}$ is mean) and 4 points (Me is median) were shown. It is substantially better than the similar indices for standard polypropylene: 4.64 points (M) and 5 points (Me), obtained in the same investigation [37]; 5.81 points (M) in another one [36], about 5 points in the third $[34,39]$, and $6-7$ points in the fourth research [12]. It is because of serious intraabdominal complications that the standard polypropylene mesh is not recommended to be used by IPOM technique [18]. In recent years, more advanced materials with different chemical composition are being actively studied, such for example, as polyvinylidene fluoride, whose index of the adhesive process intensity after IPOM was found to be from 2 to 3.15 points without antiadhesive coatings, and from 1.39 to 2 points with their application [12, 37].

Notably, that the danger of intraperitonial implantation of a standard polypropylene mesh widely known in the herniological sphere is not adequately grounded in terms of evidence-based medicine, which is convincingly set forth in detail in the work of Ramakrishna [14].

Nevertheless, retromuscular repair remains a standard of safety in relation to the development of adhesive process, which is proved within the frames of the given and earlier investigations [38] for ultralightweight synthetic and titanium-containing meshes. This statement is also true for the lightweight and standard synthetic meshes, which was substantiated by us in previous studies [40].

The feasibility of intraabdominal implantation of titanium-containing mesh meshes has already attracted attention abroad [29, 41]. It has been shown that the results of intraperitonial repair using meshes from polypropylene with a titanium coating (TiMesh) are not inferior to the meshes from the stretched polytetrafluoroethylene (ePTFE) after their intraperitoneal placement [41], the material which has been considered for a long time to be a standard of implant for IPOM [34, 39]. However, according to the data of the conducted experimental work and the analysis of the latest publications it may be supposed that an optimal mesh for IPOM has not yet been proposed. It is unlikely that this problem will be overcome in the nearest time. It is mainly connected with the specificity of the methodology rather than with only constructive or technical drawbacks of any given implant.

All the above said determines the necessity of investigating the possibility of using ultra-lightweight synthetic and titanium-containing meshes for the reconstruction of the abdominal wall by means of retromuscular repair. And the application of the titaniumcontaining meshes seems to be more preferable as they are associated with the formation of reliably stronger connective tissue in the zone of implantation [42], and the inflammatory reaction induced by a titaniumcontaining mesh is substantially less than by a synthetic mesh [43].

The point of view presented in this work about the necessity of a wide usage of lightweight and ultralightweight meshes has been sufficiently substantiated 
by clinical and experimental data, but does not coincide with the position of some researchers in Russia and abroad [8, 35]. It should be clearly understood that preference of using lightweight and ultra-lightweight materials should be given only in case of performing adequate reconstruction of the abdominal wall by retromuscular plastic method, and in difficult situations by the technique of component separation. It is also necessary to take into consideration the known risk factors of hernia recurrence.

Conclusion. Retromuscular repair with the help of ultra-lightweight synthetic and titanium-containing meshes should be used for the reconstruction of the abdominal wall. This approach is an experimentally grounded, reliable and safe solution associated with minimal formation of viscero-parietal adhesions in the zone of implantation.

Study Funding. The work was supported by the Ministry of Education and Science of the Russian Federation, unique project identifier RFMEFI60714X0085.

Conflicts of Interest. The authors have no conflicts of interest to declare.

\section{References}

1. Golovin R.V., Nikitin N.A. The assessment of different combination prosthetic repair techniques and prognostic criteria for early wound complications in median incisional ventral hernias. Sovremennye tehnologii v medicine 2015; 7(2): 105-112, https://doi.org/10.17691/stm2015.7.2.14.

2. Ermakov N.A., Zorin E.A., Orlovskaya E.S., Lyadov K.V. Methods of releasing partial rectus abdominis for the full restoration of the white line after trailing the separation of plastic over the large and giant postoperative ventral hernias. Moskovskiy khirurgicheskiy zhurnal 2015; 4(44): 22-25.

3. Yurasov A.V., Shestakov A.L., Kurashvili D.N., Abovyan L.A. The modern concept of surgical treatment of patients with postoperative hernias of the anterior abdominal wall. Vestnik eksperimental'noy i klinicheskoy khirurgii 2014; 4(7): 405-413.

4. Köckerling F., Botsinis M.D., Rohde C., Reinpold W. Endoscopic-assisted linea alba reconstruction plus mesh augmentation for treatment of umbilical and/or epigastric hernias and rectus abdominis diastasis - early results. Front Surg 2016; 3: 27, https://doi.org/10.3389/fsurg.2016.00027.

5. Molchanov M.A. Intraperitoneal plastics of postoperative and umbilical hernias. Aspirantskiy vestnik Povolzh'ya 2015; 1-2: 157-162.

6. Langbach O., Bukholm I., Benth J.Š., Røkke O. Long term recurrence, pain and patient satisfaction after ventral hernia mesh repair. World $J$ Gastrointest Surg 2015; 7(12): 384-393, https://doi.org/10.4240/wjgs.v7.i12.384.

7. Belokonev V.I., Zhitlov A.G., Vavilov A.V. Pathomorphological rationale of surgical treatment principles of patients with incisional ventral hernia. Byulleten' meditsinskikh internet-konferentsiy 2011; 1(6): 62-102.

8. Anurov M.V., Titkova S.M., Ettinger A.P. Classification of prostheses for abdominal hernia repair: analytical literature review. Vestnik Rossiyskogo gosudarstvennogo meditsinskogo universiteta 2015; 1: 5-10.
9. Netyaga A.A., Parfenov A.O., Nutfullina G.M., Zhukovsky V.A. Effect of different prosthetic meshes for hernia repair on the muscles of different parts of the abdominal wall (experimental study). Kurskiy nauchno-prakticheskiy vestnik "Chelovek i ego zdorov'e" 2013; 4: 26-32.

10. Siassi M., Mahn A., Baumann E., Vollmer M., Huber G., Morlock M., Kallinowski F. Development of a dynamic model for ventral hernia mesh repair. Langenbecks Arch Surg 2014; 399(7): 857-862, https://doi.org/10.1007/s00423-014-1239-x.

11. Ponomareva Y.V., Belokonev V.I., Volova L.T., Gulyaev M.G. The morphological basis of the causes of recurrence in patients with postoperative ventral hernias. Fundamental'nye issledovaniya 2013; 9(2): 263-266.

12. Chistyakov D.B., Movchan K.N., Yaschenko A.C. The intensity of the formation of adhesions in the process of intra-abdominal strengthening of the abdominal wall in the experiment synthetic mesh implants, different physical-to-chemical basis of the structure. Vestnik SeveroZapadnogo gosudarstvennogo meditsinskogo universiteta im. I.I. Mechnikova 2015; 3(7): 29-37.

13. Mayagoitia-González J.C., Gudiño-Amezcua L.M., Rivera-Barragán V., Mellado-Díaz A.V., Díaz-Chávez E.P. Prevention of intestinal adhesions as a result of intraperitoneal mesh with the addition of hyaluronic acid/carboxymethylcellulose gel. Experimental model in rats. Cir Cir 2012; 80(2): 150-156.

14. Ramakrishna H.K., Lakshman K. Intra peritoneal polypropylene mesh and newer meshes in ventral hernia repair: what EBM says? Indian J Surg 2013; 75(5): 346-351, https://doi.org/10.1007/s12262-012-0743-x.

15. Langbach O., Holmedal S.H., Grandal O.J., Røkke O. Adhesions to mesh after ventral hernia mesh repair are detected by MRI but are not a cause of long term chronic abdominal pain. Gastroenterol Res Pract 2016; 2016: 2631598, https://doi.org/10.1155/2016/2631598.

16. Diamond M.P., Burns E.L., Accomando B., Mian S., Holmdahl L. Seprafilm ${ }^{\circledR}$ adhesion barrier: (1) a review of preclinical, animal, and human investigational studies. Gynecol Surg 2012; 9(3): 237-245, https://doi.org/10.1007/s10397-0120741-9.

17. Bazaev A.V., Goshadze K.A., Malov A.A., Yanyshev A.A. Migration of polypropylene mesh into the abdominal cavity after hernia repair of recurrent postoperative ventral hernia (clinical case). Vestnik novykh meditsinskikh tekhnologiy 2016; 23(1): 59-61.

18. Sahoo M.R., Bisoi S., Mathapati S. Polypropelene mesh eroding transverse colon following laparoscopic ventral hernia repair. J Minim Access Surg 2013; 9(1): 40-41, https:// doi.org/10.4103/0972-9941.107139.

19. Reslinski A., Dabrowiecki S., Glowacka K. The impact of diclofenac and ibuprofen on biofilm formation on the surface of polypropylene mesh. Hernia 2015; 19(2): 179-185, https:// doi.org/10.1007/s10029-013-1200-x.

20. Postnikov D.G., Pavlenko V.V., Krasnov O.A., Oorzhak O.V., Egorova O.N., Lesnikov S.M. Problems of prophylaxis of wound complications at patients with postoperative ventral hernias. Meditsina $i$ obrazovanie $v$ Sibiri 2015; 3: 73.

21. Pushkin S.Yu., Belokonev V.I., Shifrin G.I., Larina T.V., Klyuev K.E., Kuznetsov O.E. The nature of morphofunctional changes in tissues in the formation of liquid masses in subcutaneous tissue in patients after herniotomy. Novosti khirurgii 2011; 19(2): 16-20.

22. Egiev V.N., Shurygin S.N., Chizhov D.V. The 
comparison of abdominal wal plasty with "heavy" and "light" polypropylene endoprostheses in the treatment of incisional ventral hernias. Moskovskiy khirurgicheskiy zhurnal 2012; 2: 20-23.

23. Kazantsev A.A., Parshikov V.V., Shemyatovsky K.A., Alekhin A.I., Titarov D.L., Kolpakov A.A., Osadchenko S.V. The titanium-containing mesh as a perspective group of implants for abdominal wall repair. Khirurgiya. Zhurnal im. N.I. Pirogova 2016; 4: 86-95.

24. Schopf S., von Ahnen T., von Ahnen M., Schardey H. Chronic pain after laparoscopic transabdominal preperitoneal hernia repair: a randomized comparison of light and extralight titanized polypropylene mesh. World J Surg 2011; 35(2): 302310, https://doi.org/10.1007/s00268-010-0850-4.

25. Parshikov V.V., Samsonov A.V., Romanov R.V., Gradusov V.P., Samsonov A.A., Khodak V.A., Petrov V.V., Tsybusov S.N., Baburin A.B., Kihlyarov P.V., Kazantsev A.A. The first experience of tension-free abdominal wall repair with titan mesh. Meditsinskiy al'manakh 2011; 1(20): 107-110.

26. Kolpakov A.A., Kazantsev A.A. Comparative analysis of the results of titanium and polypropylene prostheses in patients with incisional ventral hernias. Russkiy meditsinskiy zhurnal 2015; 23(13): 774-775.

27. Chernov A.V., Irianov Yu.M., Radchenko S.A., Chernov V.F., Irianova T.Yu. Studying the integration features of different biomaterials in organism soft and bone tissues. Geniy ortopedii 2012; 1: 97-101.

28. Limonov A.V., Titov D.A., Zabrodin V.V., Valiyev E.F., Zabrodin Ye.V. Application of titanium mesh endoprosthesis for all transplantation of inguinal hernias. Meditsinskiy vestnik MVD 2014; 1(68): 49-51.

29. Köckerling F., Schug-Pass $C$. What do we know about titanized polypropylene meshes? An evidence-based review of the literature. Hernia 2014; 18(4): 445-457, https://doi. org/10.1007/s10029-013-1187-3.

30. Rukovodstvo po laboratornym zhivotnym i al'ternativnym modelyam v biomeditsinskikh tekhnologiyakh [Guidelines on laboratory animals and alternative models in biomedical technologies]. Pod red. Karkishchenko N.N., Gracheva S.V. [Karkishchenko N.N., Gracheva S.V. (editors)]. Moscow; 2010.

31. Klinge U., Klosterhalfen B. Modified classification of surgical meshes for hernia repair based on the analyses of 1,000 explanted meshes. Hernia 2012; 16(3): 251-258, https:// doi.org/10.1007/s10029-012-0913-6.

32. Coda A., Lamberti R., Martorana S. Classification of prosthetics used in hernia repair based on weight and biomaterial. Hernia 2012; 16(1): 9-20, https://doi.org/10.1007/ s10029-011-0868-z.

33. Anurov M.V.Vliyanie strukturnykh i mekhanicheskikh svoystr setchatykh protezov na effektivnost' plastiki gryzhevykh defektov bryushnoy stenki. Dis. ... dokt. med. nauk [The effect of structural and mechanical properties of mesh prostheses on abdominal wall hernia defect plasty efficacy. DSc Thesis]. Moscow; 2014.

34. Egiev V.N., Liadov V.K., Bogomazova S.lu. Intraperitoneal ventral hernia plasty: the comparison of prosthetic materials. Khirurgiya. Zhurnal im. N.I. Pirogova 2010; 10: 36-41.

35. Cobb W.S., Warren J.A., Ewing J.A., Burnikel A., Merchant M., Carbonell A.M. Open retromuscular mesh repair of complex incisional hernia: predictors of wound events and recurrence. J Am Coll Surg 2015; 220(4): 606-613, https://doi. org/10.1016/j.jamcollsurg.2014.12.055.

36. Petrov V.V., Parshikov V.V., Khodak V.A., Romanov R.V., Samsonov A.A., Dvornikov A.V., Mironov A.A. Tension-free intraperitoneal plasty of abdominal wall using composite mesh (experimental study). Sovremennye problemy nauki i obrazovaniya 2012; 2. URL: https://www.scienceeducation.ru/en/article/view? $\mathrm{id}=6062$.

37. Parshikov V.V., Samsonov A.A., Khodak V.A., Mironov A.A., Malinina O.lu. The possible ways of adhesions prophylaxis in prosthetic repair of abdominal wall (experimental study). Vestnik eksperimental'noy i klinicheskoy khirurgii 2015; 8(2): 206-213.

38. Parshikov V.V., Mironov A.A., Kazantsev A.A., Alekhin A.I. Intraperitoneal and retromuscular abdominal wall repair using ultra-light and titanium-containing polypropylene mesh (experimental research). Khirurgiya. Zhurnal im. N.I. Pirogova 2016; 4: 40-44.

39. Lyadov V.K. Sravnitel'naya otsenka materialov dlya vnutribryushinnogo razmeshcheniya pri lechenii gryzh peredney bryushnoy stenki. Eksperimental'no-klinicheskoe issledovanie. Avtoref. dis. ... kand. med. nauk [Comparative assessment of the materials for intraperitoneal usage in the treatment of anterior abdominal wall hernias. Experimental and clinical study. PhD Thesis]. Moscow; 2010.

40. Parshikov V.V., Khodak V.A., Petrov V.V., Dvornikov A.V., Mironov A.A., Samsonov A.A., Romanov R.V. Retromuscular plasty of abdominal wall using mesh. Fundamental'nye issledovaniya 2012; 7(1): 159-163.

41. Schug-Paß C., Tamme C., Tannapfel A., Köckerling F. A lightweight polypropylene mesh (TiMesh) for laparoscopic intraperitoneal repair of abdominal wall hernias. Surg Endosc 2006; 20(3): 402-409, https://doi.org/10.1007/s00464-0048277-3.

42. Parshikov V.V., Kazantsev A.A., Mironov A.A., Zavaruev V.A., Chernikov A.N., Belayev O.F., Alyokhin A.I. Strength properties of abdominal wall in intraperitoneal and retromuscular repair using lightweight and ultralightweight synthetic and titanium-containing endoprostheses (experimental study). Sovremennye tehnologii $v$ medicine 2016; 8(3): 27-36, https://doi.org/10.17691/stm2016.8.3.03.

43. Zhu L.-M. Mesh implants: an overview of crucial mesh parameters. World J Gastrointest Surg 2015; 7(10): 226, https://doi.org/10.4240/wjgs.v7.i10.226. 